\title{
New spiral bacterium in gastric mucosa
}

\author{
CLIODNA A M McNULTY, $\dagger$ JULIE C DENT, $\dagger$ A CURRY,* J S UFF, G A FORD, \\ M W L GEAR, S P WILKINSON
}

From the $\dagger$ Public Health Laboratory and Departments of Histopathology and Gastroenterology, Gloucestershire Royal Hospital, Gloucester, and * Public Health Laboratory, Withington Hospital, Manchester

SUMMARY A new spiral bacterium, distinct from Campylobacter pylori, was found in the gastric mucosa of six patients with gastrointestinal symptoms. All patients had chronic active type B gastritis and four had oesophagitis. Culture and microscopy for $C$ pylori infection was negative. These unculturable spiral organisms were probably an incidental finding in patients presenting for upper gastrointestinal endoscopy, but it is not possible to say from this small series whether these organisms cause chronic active gastritis.

The organism is helical, $3 \cdot 5-7 \cdot 5 \mu \mathrm{m}$ long and $0.9 \mu \mathrm{m}$ in diameter with truncated ends flattened at the tips, and up to 12 sheathed flagella $28 \mathrm{~nm}$ in diameter at each pole. It is proposed that this spiral bacterium should be called "Gastrospirillum hominis Gen.nov., Sp.nov."

Spiral organisms were first reported in the gastric mucosa of a dog in 1881 by Rappin'; and his observations were confirmed and extended in the dog and other mammalian species by other authors. ${ }^{2-4}$ In 1906 Krienitz described three types of spiral bacteria in the base of a gastric ulcer in a patient with gastric carcinoma. ${ }^{5}$ Since 1983 when Warren ${ }^{6}$ and Marshall ${ }^{7}$ first described Campylobacter pylori and its association with gastritis, there has been much renewed interest in gastric microbiology and histopathology. ${ }^{89}$ Between July 1986 and July 1987, while studying patients attending endoscopy clinic for the investigation of upper gastrointestinal symptoms, we found spiral organisms unlike $C$ pylori on Gram stained tissue smears from the gastric mucosa. Following our preliminary report on three patients, ${ }^{10}$ we found the bacterium in a further three patients and obtained regional biopsy specimens from three of the six.

\section{Material and methods}

The patients were part of a large study to determine the prevalence of $C$ pylori in the gastric mucosa of patients attending for upper gastrointestinal endoscopy. The study was approved by the Gloucestershire Royal Hospital ethical committee. Patients gave informed consent for endoscopy and biopsy; patients with a contraindication to biopsy were excluded. Demographic details, symptoms, medical, surgical, family, social and drug history were entered on to a computer database. When these unusual spiral organisms were found in Gram stained tissue smears of the gastric mucosa the patients' notes were examined in more detail and four patients were asked to return for a second endoscopy; three agreed (cases 1-3).

\section{ENDOSCOPY}

The oesophagus, stomach, and duodenum were examined and the appearances noted. Four mucosal specimens were taken from within $5 \mathrm{~cm}$ of the pylorus. Two specimens were sent for histological examination in $10 \%$ formol-saline, and two specimens, placed near the top of a $5 \mathrm{ml}$ bijoux bottle containing $100 \mu \mathrm{l}$ saline to maintain humidity, were sent for microbiological examination. Between each examination the flexible endoscopes (including all the channels) and biopsy forceps were disinfected by immersion in $2 \%$ glutaraldehyde for at least 10 minutes, rinsed in water, and dried. A $10 \mathrm{ml}$ sample of venous blood was taken for serology.

When the three patients returned for their second endoscopy, two biopsy specimens were taken from the first part of the duodenum, the antrum and body of the stomach, and the oesophagus. A clean biopsy forceps was used for each site. These were examined histologically as before. Six extra specimens were taken from the antrum; three were examined microbiologically and three were placed in $3 \%$ glutaraldehyde for electron microscopy. 


\section{MICROBIOLOGY}

At the patients' first endoscopy, specimens were processed within two hours. Each specimen was smeared with a swab-stick over half a glass slide for microscopy and over part of a plate of chocolate agar (10\% horse blood, Columbia agar base CM331) and half of a plate of Campylobacter selective medium (7\% lysed horse blood, Columbia agar base CM331, and vancomycin $10 \mathrm{mg} / \mathrm{l}$, cefsulodin $5 \mathrm{mg} / \mathrm{l}$, trimethoprim $5 \mathrm{mg} / \mathrm{l}$, and amphotericin $5 \mathrm{mg} / \mathrm{l}$ ). The two specimens were then crushed with the swab into $0.5 \mathrm{ml}$ of $2 \%$ urea broth for the biopsy urease test.

The smears were heat fixed and stained by Gram's method using dilute carbol fuchsin as counter stain. They were examined for the presence of spiral organisms on the day of preparation with a $\times 100$ oil immersion lens for five minutes.

The plates were incubated microaerobically $(6 \%$ oxygen, $10 \%$ carbon dioxide, $84 \%$ nitrogen, obtained by partial evacuation and replacement with a carbon dioxide/nitrogen gas mixture) at $37^{\circ} \mathrm{C}$ and examined at three, five, and seven days for the presence of growth.

The biopsy urease tests were left at room temperature and examined regularly until $6 \mathrm{pm}$ on the day of preparation, and again the next morning. A positive result was indicated by a colour change from yellow to pink.

The specimens from the three patients who returned for their second endoscopy were treated in the same way except that they were processed immediately and plated on a wider range of media in atmospheres: anaerobic (Don Whitley anaerobic cabinet, 10\% carbon dioxide, $10 \%$ hydrogen, $80 \%$ nitrogen); aerobic (air); microaerobic (as above); and in $10 \%$ carbon dioxide in air (table 1). The broths were incubated microaerobically and anaerobically and were examined for turbidity and subcultured on to chocolate agar and the $C$ pylori selective media at seven, 14, and 21 days. Plates were examined at three, five, seven, 14, 21 and 28 days; Gram stained smears were prepared from any colonies.

\section{HISTOPATHOLOGY}

Biopsy specimens fixed in formalin were processed to paraffin wax in the usual way. Sections were stained by haematoxylin and eosin and the half Gram method." Biopsy specimens were assessed by a histopathologist without knowledge of patient details. Any pathology was noted and the degree of gastritis was graded according to the extent of inflammatory infiltrate on the haematoxylin and eosin stained sections. The presence or absence of Campylobacter-like or spiral organisms was noted on the half Gram stained sections, with a $\times \mathbf{4 0}$ objective (oil immersion was not required) and the number of organisms scored from zero to three-plus: $0=$ no bacteria seen;
Table 1 Media and atmospheres used for attempted culture of spiral organisms

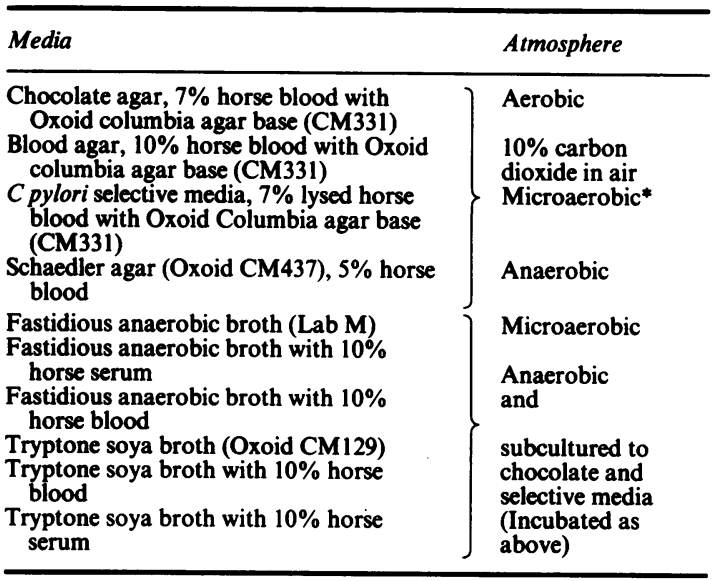

*6\% oxygen, $10 \%$ carbon dioxide.

$3+=$ numerous bacteria in all fields. Gastric mucosal tissue sections prepared from specimens taken at previous endoscopies were reviewed for cases 1-3.

\section{ELECTRON MICROSCOPY}

Biopsy material from cases 1-3 was fixed in $3 \%$ glutaraldehyde for one week and then post-fixed in $1 \%$ cacodylate buffered osmium tetroxide, dehydrated in a graded series of alcohols and embedded in Agar 100 resin (Agar Aids). Thin sections were cut on a Reichert OMU4 Ultracut ultramicrotome, mounted on uncoated copper grids, stained with uranyl acetate followed by lead citrate and examined in an AEI EM 801 electron microscope. Images were photographically recorded on Ilford EM film.

\section{Results (table 2)}

This unusual spiral bacterium was first seen in the microbiology department by JCD on a Gram stained tissue smear with the oil immersion lens. The histopathologist was then alerted to this new bacterium and the organisms were subsequently found in six of 1650 patients. Gram stained tissue smears were positive in seven of 10 specimens and histological sections were positive in eight of 10 specimens (table 2).

\section{CASE HISTORIES (table 3)}

\section{Microbiology}

The Gram negative spiral organisms were morphologically readily distinguishable from $C$ pylori. Unlike $C$ pylori, the spiral bacterium had from four to eight even spirals and measured up to $7.5 \mu \mathrm{m}$ (range 4-7.5 $\mu \mathrm{m}$ ) in length. The bacterium was not found 
Table 2 Detection of spiral organisms

\begin{tabular}{|c|c|c|c|c|c|c|c|}
\hline $\begin{array}{l}\text { Case } \\
\text { No }\end{array}$ & Date & $\begin{array}{l}\text { Endoscopic } \\
\text { appearance }\end{array}$ & Gram & Antibody & $\begin{array}{l}\text { Electron } \\
\text { microscopy }\end{array}$ & Histopathology & $\begin{array}{l}\text { Clinical } \\
\text { diagnosis }\end{array}$ \\
\hline 1 & $\begin{array}{l}7 / 87 \\
8 / 87\end{array}$ & $\begin{array}{l}\text { Normal } \\
\text { Body mosaic } \\
\text { pattern }\end{array}$ & $\overline{+}+$ & $\begin{array}{l}+ \\
+\end{array}$ & $\begin{array}{l}\text { NA } \\
+\end{array}$ & $\begin{array}{l}\text { Pyloric }+++ \text { /moderate CAG } \\
\text { Pyloric }++ \text { /moderate CAG } \\
\text { body }- \text { /normal } \\
\text { duodenum }- \text { /normal } \\
\text { oesophagus }- \text { /mild oesophagitis }\end{array}$ & Oesophagitis \\
\hline & $3 / 88$ & Normal & - & NA & NA & $\begin{array}{l}\text { Pyloric }+/ \text { normal } \\
\text { oesophagus }-/ \text { mild }\end{array}$ & Oesophagitis \\
\hline \multirow[t]{3}{*}{2} & $8 / 81$ & Oesophagitis & NA & NA & NA & $\begin{array}{l}\text { Pyloric - /moderate CAG } \\
\text { body - /normal }\end{array}$ & \multirow[t]{3}{*}{ Oesophagitis } \\
\hline & $3 / 87$ & \multirow{2}{*}{$\begin{array}{l}\text { Oesophageal ulcer } \\
\text { Oesophagitis } \\
\text { Oesophagitis }\end{array}$} & + & + & + & Pyloric $++/$ severe CAG & \\
\hline & $8 / 87$ & & + & + & - & $\begin{array}{l}\text { Pyloric }+ \text { /moderate CAG } \\
\text { body }- \text { /normal } \\
\text { duodenum }- \text { /normal } \\
\text { oesophagus - /severe } \\
\text { esophagitis }\end{array}$ & \\
\hline 3 & $\begin{array}{r}11 / 86 \\
5 / 87 \\
8 / 87\end{array}$ & $\begin{array}{l}\text { Oesophagitis } \\
\text { Oesophagitis } \\
\text { Oesophagitis }\end{array}$ & $\begin{array}{l}+ \\
\text { NA } \\
+\end{array}$ & $\begin{array}{l}\overline{N A} \\
-\end{array}$ & $\begin{array}{l}\overline{\mathbf{N A}} \\
-\end{array}$ & $\begin{array}{l}\text { Pyloric }+ \text { /mild CAG } \\
\text { Oesophagus }- \text { /mild oesophagitis } \\
\text { Pyloric }- \text { /normal } \\
\text { body }- \text { /normal } \\
\text { duodenum - /normal }\end{array}$ & Oesophagitis \\
\hline 4 & $6 / 86$ & Normal & NA & NA & NA & Duodenum - /normal & $\begin{array}{l}\text { Dietary } \\
\text { deficiency }\end{array}$ \\
\hline $\begin{array}{l}5 \\
6\end{array}$ & $\begin{array}{l}8 / 86 \\
4 / 88 \\
6 / 87\end{array}$ & $\begin{array}{l}\text { Normal } \\
\text { Oesophageal ulcer } \\
\text { Normal }\end{array}$ & $\begin{array}{l}+ \\
+ \\
-\end{array}$ & $\begin{array}{l} \pm \\
-\end{array}$ & $\begin{array}{l}\text { NA } \\
\text { NA } \\
\text { NA }\end{array}$ & $\begin{array}{l}\text { Pyloric }- \text { /mild CAG } \\
\text { Pyloric }+ \text { /mild CAG } \\
\text { Pyloric }+/ \text { mild CAG } \\
\text { duodenum - /normal }\end{array}$ & $\begin{array}{l}\text { Oesophagitis } \\
\text { Infective } \\
\text { enteritis }\end{array}$ \\
\hline
\end{tabular}

NA: not available; +-+++ : Number of organisms; CAG: chronic active gastritis.

evenly throughout tissue smears and could be missed if smears were not examined for five minutes. They were usually found in large distinct groups aligned in the mucus.

Culture for spiral organisms was negative in all cases. Campylobacter-like organisms were not seen and culture for $C$ pylori, which is usually very sensitive, ${ }^{12}$ was negative. The biopsy urease test was positive in case 1 . Antibody to $C$ pylori urease antigen ${ }^{13}$ was detected in cases 1,2 , and 4 (table 2).
Histopathology

For most patients biopsy specimens were available only from the pylorus. The spiral bacteria were readily seen with the $\times 40$ objective in sections stained with haematoxylin and eosin or the half Gram stain. The half Gram is not essential for screening for these spiral organisms but facilitates the detection of $C$ pylori that stains faintly with haematoxylin and eosin. The spiral bacteria were seen in large groups in the necks of the pyloric glands and on the mucosal surface within or

Table 3 Case histories

\begin{tabular}{|c|c|c|c|c|}
\hline Case No & Sex & Age & $\begin{array}{l}\text { Animal } \\
\text { contact }\end{array}$ & Clinical details \\
\hline 1 & $\mathbf{M}$ & 30 & Pet cat & $\begin{array}{l}5 \mathrm{~m} \text { of burning epigastric pain unresponsive to antacids; organisms not cleared and } \\
\text { no symptomatic response to } \mathrm{H}_{2} \text { antagonist or bismuth subcitrate and amoxycillin } \\
\text { or metronidazole }\end{array}$ \\
\hline 2 & $\mathbf{M}$ & 57 & None & $\begin{array}{l}\text { Dyspepsia with severe oesophagitis with initial response to alginic acid/antacid; } 5 \\
\text { years later increasing symptoms with ulcerative oesophagitis at endoscopy; } \\
\text { symptomatic response to } \mathrm{H}_{2} \text { antagonist but oesophagitis and gastritis persist }\end{array}$ \\
\hline 3 & $\mathbf{M}$ & 56 & None & $\begin{array}{l}20 \text { years of posture related retrosternal burning pain; endoscopy showed severe } \\
\text { oesophagitis; symptoms progressively resistant to medical treatment; he } \\
\text { underwent a successful anti-reflux operation }\end{array}$ \\
\hline 4 & $\mathbf{F}$ & 24 & None & $\begin{array}{l}\text { Symptoms of peripheral neuropathy; macrocytosis and marginally reduced blood } \\
\text { B12 and folic acid; duodenal biopsy excluded coeliac disease; deficiencies } \\
\text { attributed to poor diet }\end{array}$ \\
\hline 5 & $\mathbf{F}$ & 79 & None & $\begin{array}{l}\text { Epigastric pain and small haematemesis; deep oesophageal ulcer, oesophagitis, and } \\
\text { pseudodiverticulum at oesophagogastric junction; symptomatic response to } \\
\text { alginic/antacid and } \mathrm{H}_{2} \text { blocker combination }\end{array}$ \\
\hline 6 & $\mathbf{M}$ & 17 & Animal carcasses & $\begin{array}{l}\text { Acute onset of fever, right iliac fossa pain, diarrhoea lasting four days; stool culture } \\
\text { negative; rectal biopsy compatible with infective enteritis; second episode } 3 \\
\text { months later with } 7 \text { lb weight loss and polyarthropathy; small bowel barium study } \\
\text { and duodenal biopsies to exclude Whipples' disease normal; symptoms resolved }\end{array}$ \\
\hline
\end{tabular}




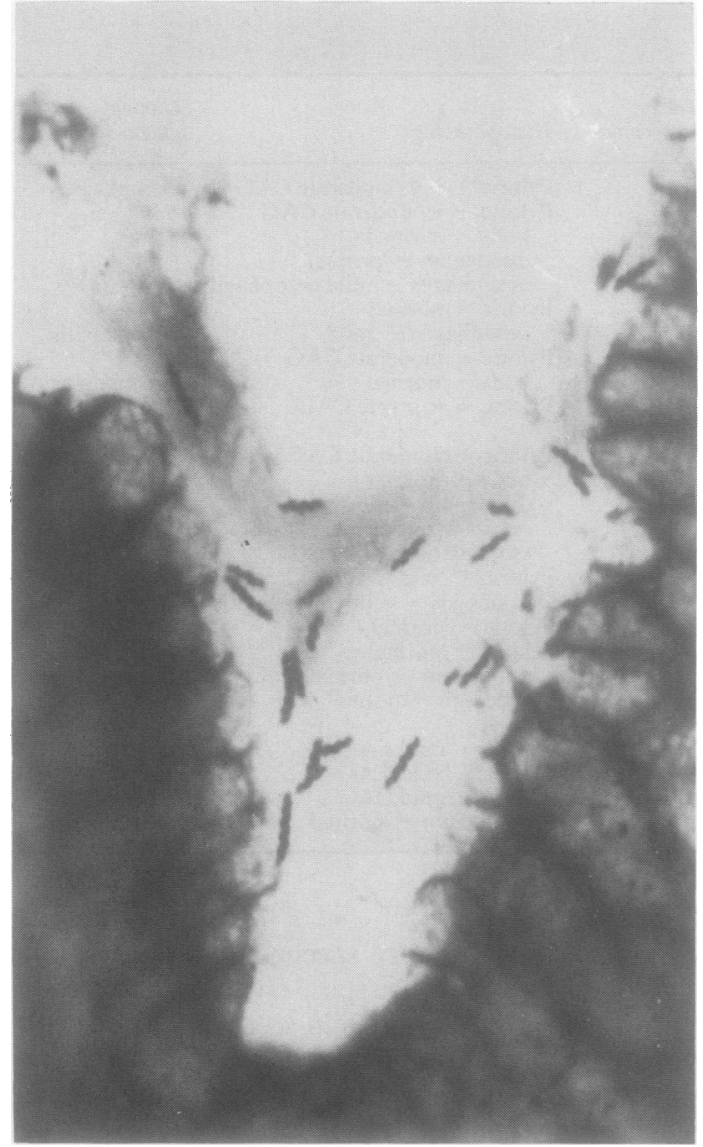

Fig 1 Section through pyloric gland showing groups of spiral organisms in neck and on mucosal surface (Half Gram.)

beneath the mucus (fig 1). The bacterium did not extend into the bottom of the pits. In all cases the bacterium was associated with a chronic active gastritis indistinguishable from $C$ pylori gastritis (figs 2 and 3), but Campylobacter-like organisms were not seen in any case, despite review of all sections on three occasions. There was a polymorphonuclear and mononuclear infiltration in the lamina propria with some flattening of the superficial epithelial cells. There were no organisms or inflammatory cell infiltration in the duodenal specimens of four patients or the body specimens of three patients taken at the same time as positive pyloric specimens. Interestingly, although oesophagitis was present in the three patients from whom oesophageal specimens were available, spiral bacteria were not seen. The infection is chronic as spiral bacteria were seen in pyloric specimens taken from the same patients (cases 1, 2, and 3) five to nine months apart (table 2). Case 2 had had an endoscopy

six years previously in 1981; although moderate chronic active gastritis was present in the pyloric mucosa, no organisms were seen. The severity of the gastritis increased with the number of organisms present. Patients $3,4,5$ and 6 only had scanty organisms with a mild gastritis. Cases 1 and 2 had more organisms with a more severe gastritis; this had improved by their second endoscopy in parallel with the number of organisms.

\section{Electron microscopy}

Electron microscopy was done on five specimens from three patients; spiral organisms were found in two patients (table 2); $C$ pylori was not seen. Spiral organisms were not found in the other specimens, probably through chance as they were most commonly found in large localised groups; the very thin sections prepared for electron microscopy meant that these groups could be easily missed. The groups of organisms were found in the necks of pyloric crypts and in

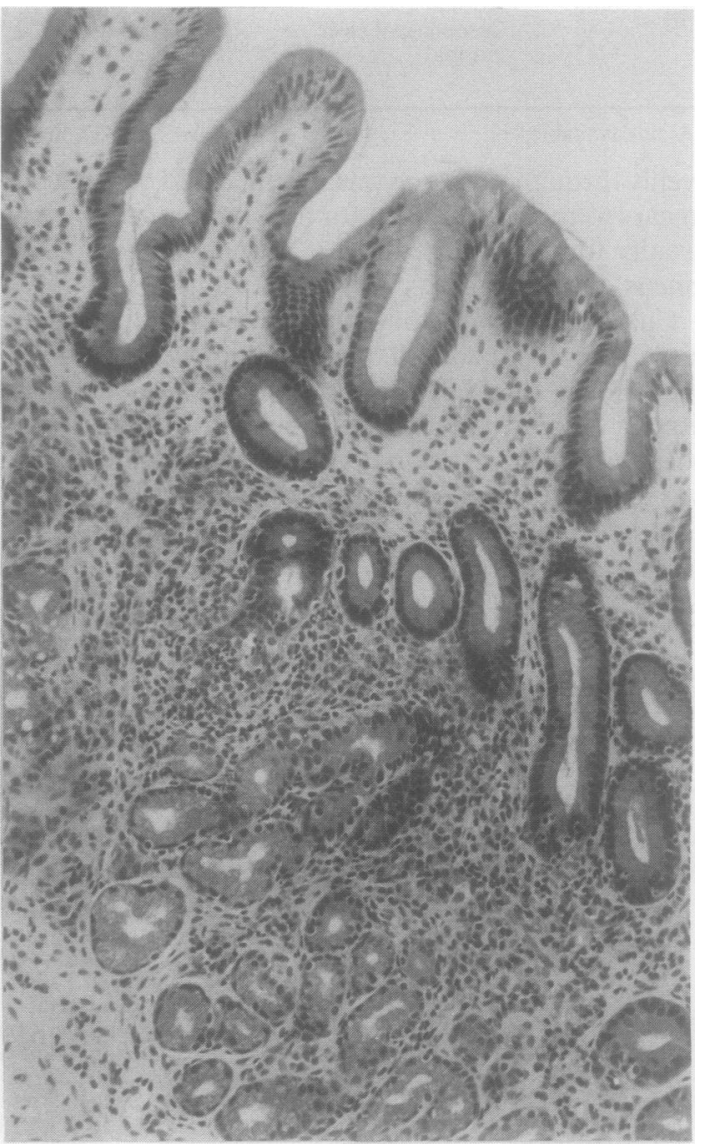

Fig 2 Chronic active gastritis indistinguishable from $C$ pylori. (Haematoxylin and eosin.) 
New spiral bacterium in gastric mucosa

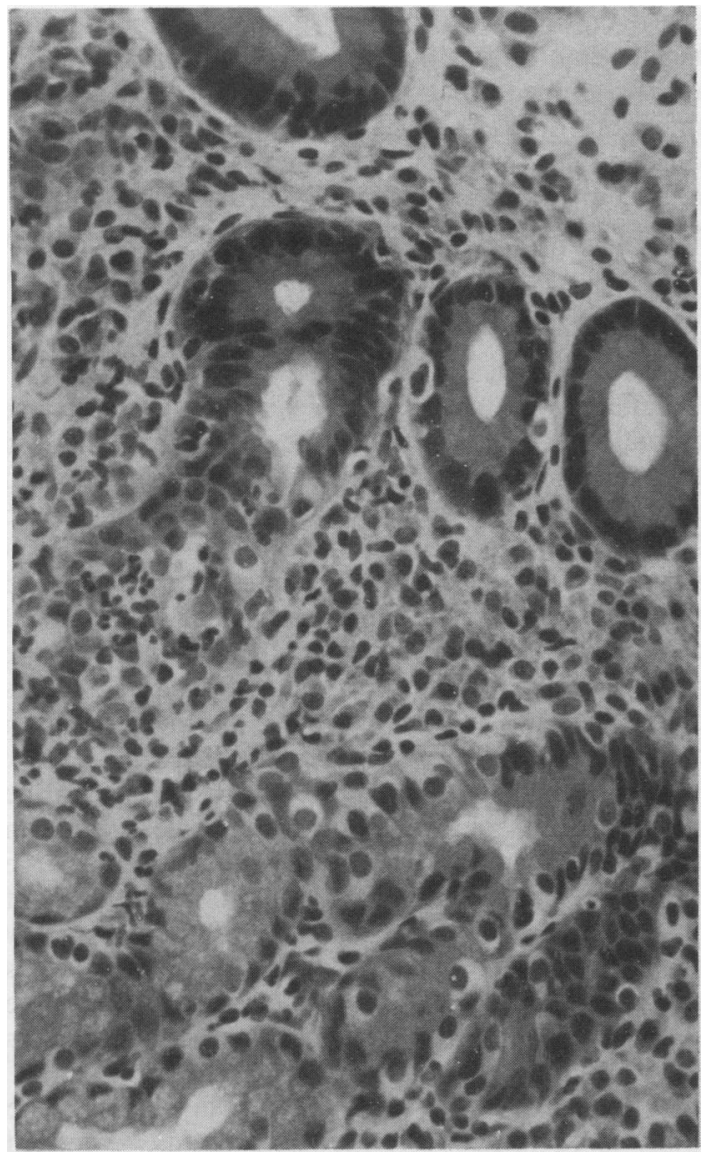

Fig 3 Section through lamina propria showing neutrophil infiltration into pyloric glands. (Haematoxylin and eosin.)

mucus on the mucosal surface. The bacteria were near the mucosal surface but there was no intimate contact with the microvilli as in $C$ pylori infection. The bacterium was not found deep within the crypts, in intercellular spaces, or in polymorphonuclear cells. No oxyntic cells were seen in the specimens examined.

The organism was tightly spiralled, about 3.5 to $4.5 \mu \mathrm{m}$ long in favourable sections and $0.6 \mu \mathrm{m}$ wide, but because of its spiral form, its overall width spans 0.8 to $0.9 \mu \mathrm{m}$ (fig 4). No sections through longer forms were attained. The diameter of the organism varied slightly according to its position on the gastric mucosa. There were about four and half turns over the length of the organism, one turn to every 0.8 to $1 \mu \mathrm{m}$. The bacterium had truncated poles with flattened ends, although rounded ends were occasionally found. The organism had a Gram negative cell wall structure comprising two membranes. The inner plasma membrane had an electron dense thickening on the proto-

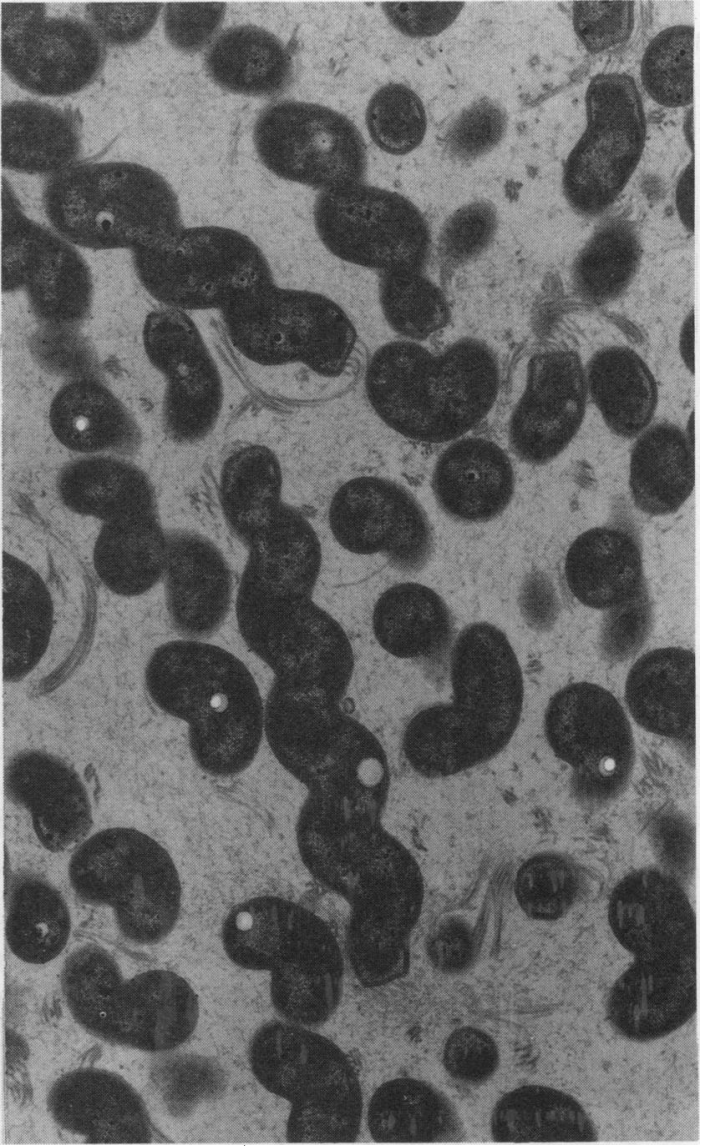

Fig 4 Large group of bacteria showing terminal bunches of sheathed flagellar filaments.

plasmic surface of the terminal region. Internal to this thickened plasma membrane there was a protoplasmic electron lucent zone. Sheathed flagellar filaments (28 $\mathrm{nm}$ in diameter) were present at both ends of the organism. From the thin sectioned material available it was difficult to be certain of the number of filaments present at each end, but 12 seemed to be average.

\section{Discussion}

Although many reports of $C$ pylori in gastric biopsy specimens have been published since 1984, none describe this new spiral bacterium. For several reasons the organisms may have been missed: most studies on $C$ pylori have been small and the incidence of this spiral organism is low. Alternatively, the organisms may have been seen but not recognised as unusual. Since our initial report ${ }^{10}$ the organism has been observed by others. ${ }^{14}$ The only previous description of 
spiral organisms unlike $C$ pylori in the human stomach was a short report by Krienitz in $1906 .{ }^{5} \mathrm{He}$ described the microscopy of the stomach contents, including vomit of a patient with carcinoma of the lesser curvature of the stomach. He identified three types of spiral bacteria: one of similar size and shape to our new spiral organism; one like $C$ pylori; and the third a spirochaete. This study, however, did not include microscopy of the gastric mucosa.

By contrast, spiral bacteria have been described in several other mammals. Spiral organisms were first described in the dog by Rappin in 1881 and called Spirillum rappini. ${ }^{1}$ This work was confirmed by Bizzozero in $1893^{2}$ and by Salomon in $1896^{3}$ in dogs, cats, and rats. Morphologically these organisms are dissimilar to ours, are usually intracellular, found in the body and are not associated with abnormal histopathology.

Weber and Schmittdiel ${ }^{15}$ described a spiral bacteria of similar morphology and size to our organism in cats and dogs. Metal-shadowed electron micrographs showed a spirillum with bipolar multiple flagella, and all their attempts to culture the organism aerobically, microaerobically and anaerobically were unsuccessful. These factors suggest that our organism may be closely related to this dog organism but in the dog colonisation was not associated with a chronic active gastritis. Similar spiral bacteria have recently been described in one of man's close relatives-the baboon. ${ }^{16}$ The baboon organism is of similar size and morphology but some of the baboon bacteria are intracellular and have an outer membrane-like wall component which is not closely adherent to the body spiral, producing a "cigar-shaped" profile.

It may be that due to sampling error and the patchy nature of the organism we did not detect the intracellular organisms that are so commonly seen in other mammals. Dya et al, however, have described the human spiral bacterium within the gastric parietal cells of a 36 year old woman. ${ }^{14}$ Like our patients, she had chronic active gastritis.

Lee et al have recently successfully cultured microaerobically a cat gastric spiral bacterium they call CS1 (cat spiral 1). ${ }^{17}$ The organism is very strongly urease positive. Our spiral organism also probably produces urease. The biopsy urease test was positive in the only patient (case 1) who had numerous organisms seen by histological and electron microscopical examination. The other patients may have had insufficient organisms present to produce a positive test. Three of the patients $(1,2$, and 4$)$ also had antibody to $C$ pylori urease. Although possible, we believe that it is unlikely that the positive biopsy urease test and serology are due to concomitant $C$ pylori infection as the combination of detection of $C$ pylori by Gramstain, culture, and histopathology is very sensitive. ${ }^{13}$ Repeated biopsy specimens were $C$ pylori negative and tissue smears and histological sections were examined at least three times to exclude double infection. In a serological study serum from three of our patients with spiral bacteria reacted with the antigen prepared from Lee $e t$ al's cat spiral organism, suggesting that these organisms are antigenically related. ${ }^{17}$ All the animal spiral bacteria may have adapted to an ecological niche in the acidic fundal areas of the gastric mucosa by producing urease, and may be antigenically related.

Patients were asked if they kept pets or had close animal contact as we thought they could have acquired their infections from animals. Case 1 owned a dog and cat but insisted he kept them at arms' length. Case 6 had a dog and worked as a slaughterman in a slaughterhouse where they killed sheep, cattle, and pigs. The other patients had no pets or close animal contact. Most mammals including pigs and cattle probably have gastric spiral bacteria and our patients could have been infected by handling or eating contaminated, raw, or undercooked meat.

The human organisms are unlikely just to be contaminants from the mouth as they were found in the same patients several months apart and in large numbers beneath the mucus and within the necks of the pyloric glands. These spiral bacteria were probably not responsible for the patients' presenting symptoms as another cause was found in all bar case 1. Unlike animals colonised with spiral bacteria, all our patients had a chronic active gastritis indistinguishable from $C$ pylori gastritis. It is difficult to establish whether these organisms simply colonise an already damaged mucosa or are pathogenic. The severity of gastritis certainly increases with the number of organisms present. It would be very interesting to see if eradication of the organism coincided with resolution of gastritis. Case 1 received antimicrobial treatment; the number of organisms decreased and the histology improved, but complete eradication did not occur. The clinical importance of the accompanying oesophagitis in four patients is unknown as spiral organisms were not seen in the oesophageal specimens. It is our conclusion that these spiral organisms were an incidental finding in patients presenting for upper gastrointestinal endoscopy. Further observation and characterisation of this organism is needed. If in vitro culture continues to be unsuccessful, animal inoculation may be appropriate.

It is tempting, although maybe slightly premature, to suggest a name for this new bacterium. The present classification must rely on morphology: it is a Gram negative spiral bacterium, though not a spirochaete as it has no axial filament. Provisional placing would be the family Spirillaceae which consists of aerobic or microaerophilic spiral bacteria. It may then be most 
appropriate to put all the spiral bacteria except $C$ pylori described in the gastric mucosa of animals into a new genus called "Gastrospirillum" (Gr. n. gastr, pertaining to the stomach; Gr. n. spira a spiral; M.L. dim. neut. n. spirillum a small spiral; Gastrospirillum a small stomach spiral). In accordance with rule 18 of the international code of nomenclature, which permits classification based on electron microscopy, we propose that the human spiral bacterium should form a species of bacterium within a new genus "Gastrospirillum" and should be called "Gastrospirillum hominis".

\section{References}

1 Rappin J. Contre à l'étude de bacteri de la bouche à l'état normal. 1881;68. Quoted by Breed RS, Murray EGD, Hitchens AP. Bergey's manual of determinative bacteriology, 6th ed. Baltimore: Williams and Wilkins Co, 1948:217.

2 Bizzozero G. Ueber die schlauchformigen drusen des magendarmkanals und die beziehungen ihres epithels zu dem oberflachenepithel der schleimhaut. Archiv fur Mikrofkopische Anatomie Entwickiungs mechanik 1893;42:82.

3 Salomon $\mathbf{H}$. Ueber das spirillum des saugetiermagens und sein verhalten zu den belegzellen. Centralblatt fur Bakteriologie, Parasitenkunde V. Infektionskrankheiten 1986;XIX:433-43.

4 Balfour A. A haemogregarine of animals and some notes on trypanosomiasis in the Anglo-Egyptian Sudan. $J$ Trop Med 1906;9:81-92.

5 Krienitz W. Ueber das auftreten von spirochaten verschiedener form im mageninhalt bei carcinoma ventriculi. Deutsch Med Wochenschr 1906;22:872.
6 Warren JR. Unidentified curved bacilli on gastric epithelium in active chronic gastritis. Lancet 1983;i:1273.

7 Marshall B. Unidentified curved bacilli on gastric epithelium in active chronic gastritis. Lancet 1983;i:1273-4.

8 Marshall BJ. Campylobacter pyloridis and gastritis. J Infect Dis 1986;153:650-6.

9 Blaser MJ. Gastric Campylobacter-like organisms, gastritis and peptic ulcer disease. Gastroenterology 1987;93:371-83.

10 Dent JC, McNulty CAM, Uff JC, Wilkinson SP, Gear MWL. Spiral organisms in the gastric antrum. Lancet 1987;ii:96.

11 Trowell JE, Yoong AKH, Saul KJ, Gant PW, Bell GD. Simple half Gram stain for showing presence of Campylobacter pyloridis in sections. J Clin Pathol 1987;40:702.

12 McNulty CAM, Dent JC, Uff JS, Gear MWL, Wilkinson SP. Detection of $\mathrm{C}$ pylori by the biopsy urease test-an assessment in 1445 patients. Gut 1989 (In press).

13 Dent JC, McNulty CAM, Uff JS, Gear MWL, Wilkinson SP. Campylobacter pylori urease: a new serological test. Lancet 1988;i:1002.

14 Dya KR, Marshall BJ, Fnerson HF, Onerrant RT, McCall RW. Gastritis in a human due to infection with an organism resembling the cat gastric spirillum. Gastroenterology 1988;94:A108.

15 Weber AF, Schmittdiel EF. Electron microscopic and bacteriologic studies of spirilla isolated from the fundic stomachs of cats and dogs. Am J Vet Res 1962;23:422-7.

16 Curry A, Jones DM, Eldridge J. Spiral organisms in the baboon stomach. Lancet 1987;ii:634-5.

17 Lee A, Dent J, Hazell S, McNulty CAM. Origin of spiral organisms in human gastric antrum. Lancet 1988;i:300-1.

Requests for reprints to: Dr Cliodna A M McNulty, Public Health Laboratory, Gloucestershire Royal Hospital, Great Western Road, Gloucester GL1 3NN, England. 